\title{
Kajian Tarif Pembebasan Bea Masuk E-Commerce Berdasarkan Peraturan Menteri Nomor 112/PMK.04/2018
}

\section{Chusnul Qotimah Nita Permata \\ Mahasiswa Fakultas Hukum, UNNES \\ Semarang, Indonesia}

Surel: Chusnulqotimahnitapermata@gmail.com

\author{
Qotrun Nada \\ Mahasiswa Fakultas Hukum, UNNES \\ Semarang, Indonesia \\ Surel: Qotrunnada1927@gmail.com
}

\section{Muhammad Iqbal Baiquni \\ Mahasiswa Fakultas Hukum, UNNES \\ Semarang, Indonesia \\ Surel: M.iqbalbaiquni@gmail.com}

\begin{abstract}
ABSTRAK
Perkembangan Industri 4.0 memberikan dampak yang besar dalam Perdagangan Internasional. Indonesia melakukan Perdagangan Internasional dengan kegiatan impor dan ekspor barang. Perdagangan Internasional sekarang sudah mudah untuk di akses oleh semua kalangan melalui online shop. Setiap kegiatan Perdagangan Internasional diikuti oleh kewajiban akan kepabeanan, salah satunya adalah pembayaran bea masuk, bea keluar dan pajak. Berdasarkan data yang dikeluarkan oleh kemenkeu.go.id, pada tahun 2015 penerimaan negara yang berasal dari bidang kepabeanan menyumbang sebesar $10,2 \%$ dari pendapatan negara. Hal ini menunjukkan bahwa bidang kepabeanan ikut berperan dalam penerimaan negara oleh karena itu perlu untuk dilakukan pengawasan. Indonesia sebagai negara berkembang masih berada dalam standar yang biasa mengenai kesejahteraan masyarakatnya, bahkan ada sebagian kecil masyarakat yang belum mengenyam yang namanya kesejahteraan. Penulis dalam tulisan ini menfokuskan kepada bea masuk, penulis berpendapat bahwa bea masuk bisa menyumbang dana yang lumayan dalam rangka peningkatan kesejahteraan masyarakat.
\end{abstract}

\section{RIWAYAT ARTIKEL}

Article History

Diterima : 28 Agustus 2019

Dipublikasi : 25 November 2019

\section{KATA KUNCI}

Keywords

Tarif Pembebasan bea Mauk

E-Commerce, Kesejahteraan

HOW TO CITE :

Permata, C.Q.N., Nada.Q., Baiquni.M.I (2019). "Kepastian Tarif Bea Masuk E-Commerce Berdasarkan Peraturan Menteri Nomor 112/PMK.04/2018", Lex Scientia Law Review. Volume 3 Nomor 2, November, HIm. 143-154 


\section{PENDAHULUAN}

Sesuai Undang-Undang Dasar Negara Republik Indonesia pada Pasal 1 Ayat 3 yang berbunyi "Negara Indonesia adalah negara hukum".(UUD NRI 1945, Pasal 1) Indonesia merupakan negara hukum yang bersumber dari Pancasila dan UUD NKRI 1945. Menurut Kemenkeu dalam penjelasan atas Undang-Undang Nomor 10 Tahun 1995 tentang Kepabeanan Umum menjelaskan bahwa setelah kemerdekaan Indonesia belum ada UndangUndang yang mengatur tentang Kepabean dibentuk, hingga saat ini masih menggunakan hukum Belanda yaitu Indische Tarief Wet (Undang-Undang Tarif Indonesia) yang mengatur tentang Kepabean bea masuk dan menentukan perimbangan sesuai ketentuan tersebut.(Kementerian Keuangan, 2019)

Dalam pelaksanan aturan kepabean Indonesia diatur Undang-Undang Kepabean (UU Nomor 17 Tahun 2006) mengenai pengaturan bea masuk atas barang impor, dimana dalam Undang-Undang tersebut sebagai kewenangan Pejabat Bea dan Cukai dalam menetapkan tarif dan nilai kepabean untuk melakukan pengawasan, pemeriksaan dan pencegahan terhadap sarana pengangkutan.

Berkaitan tentang kepabean, perkembangan industri 4.0 memberikan dampak yang besar dalam Perdagangan Internasional dan Indonesia terutama pada bidang e-commerce atau perdagangan online. Indonesia dalam bidang $e$ commerce terus meningkat disetiap tahunnya yang dipengaruhi oleh kegiatan konsumtif masyarakat Indonesia terhadap barang-barang yang berasal luar negeri (Import). Menurut data dari Bank Indonesia, menyebutkan sepanjang tahun 2018 mencapai Rp 77 triliun dalam kegiatan transaksi online. (Bank Indonesia, 2019)

Dalam kegiatan transaksi online di Indonesia diatur juga dalam UndangUndang Nomor 19 Tahun 2016 tentang Informasi dan Transaksi Elektronik sebagaimana diubah oleh Undang-Undang Nomor 11 Tahun 2008 tentang Informasi dan Transaksi Elektronik.

Ditarik kembali tentang Perdagangan Internasional, bahwa dalam Perdagangan Internasional diikuti kewajiban bea masuk, bea keluar, dan 
pajak yang telah diatur. Menurut Direktorat Jendral Bea dan Cukai, pengertian bea masuk adalah pungutan negara yang dikenakan kepada barang impor. (Direktorat Jenderal Bea dan Cukai)

Bea masuk sendiri diatur dalam Undang-Undang Nomor 17 Tahun 2006 tentang Kepabean, barang impor tersebut dikenakan tarif yang diatur dalam Pasal 12. Dalam peraturan tersebut bahwa barang impor yang tidak termasuk dalam barang dilarang atau dibatasi itu boleh dikirim ke pada penerima Indonesia, dan tentang bea masuk juga diatur dalam Peraturan Menteri Keuangan (PMK) Nomor 112/PMK.04/2018 tentang Perubahan atas Peraturan Menteri Keuangan (PMK) Nomor 182/PMK.04/2016 tentang Ketentuan Impor Barang Kiriman. Dalam pasal 13 diatur tentang pembebasan bea masuk dengan nilai paling banyak FOB USD 75.00, artinya barang-barang tersebut boleh dikirim kepada penerima yang berada di Indonesia tanpa adanya pembebanan biaya masuk dengan syarat nilai barang kiriman tidak melebihi FOB USD 75.00. Apabila nilai barang kiriman melebihi FOB USD 75.00, maka barang kiriman dipungut bea masuk.

Tidak lepas dari peraturan tersebut, maka transaksi online terhadap impor juga dikenakan Peraturan Menteri Keuangan tersebut yang memberikan pembebasan bea masuk sebesar USD 75.00 tanpa adanya syarat nilai barang kiriman tidak melebihi. Disini penulis memfokuskan tulisan dalam pembahasan mengenai tarif pembebasan bea masuk yang diatur dalam Peraturan Menteri Keuangan (PMK) Nomor 112/PMK.04/2018 tentang Ketentuan Impor Barang Kiriman.

\section{Rumusan Masalah}

1. Bagaimana Pengaturan Mengenai Tarif Bea Masuk E-Commerce berdasarkan Peraturan Menteri Keuangan Republik Indonesia No. 182/PMK.04/2016 Tentang Ketentuan Impor Barang Kiriman sebagaimana telah diubah dengan Peraturan Menteri No. 112/PMK.04/2018? 
2. Bagaimana pengaruh dari penetapan penurunan tarif pembebasan bea masuk barang impor dalam kegiatan E-Commerce terhadap kesejahteraan rakyat Indonesia?

3. Bagaimana akibat hukum dari penurunan tarif bea masuk atas barang impor berdasarkan Peraturan Menteri Keuangan Republik Indonesia No.182/PMK.04/2016 Tentang Ketentuan Impor Barang Kiriman sebagaimana telah diubah dengan Peraturan Menteri No. 112/PMK.04/2018?

\section{Metode Penulisan}

Metode penulisan yang digunakan dalam melakukan penulisan ini adalah deskriptif analitis. Deskriptif analitis ialah suatu metode penulisan yang dimaksudkan untuk menggambarkan mengenai fakta-fakta berupa data dengan bahan hukum primer dalam peraturan Perundang-undangan yang terkait dan bahan hukum sekunder berupa doktrin-doktrin atau pendapat para pakar hukum terkait hukum yang mengatur tentang tarif pembebasan bea masuk e-commerce di Indonesia serta bahan tersier seperti bibliografi, Kamus Besar Bahasa Indonesia, dan kamus hukum. Melalui penulisan ini diharapkan memperoleh gambaran terkait tarif pembebasan bea masuk e-commerce di Indonesia secara komprehensif.

Metode pendekatan yang digunakan dalam penulisan adalah metode pendekatan yuridis normatif, yaitu menetapkan standar atau norma tertentu terhadap suatu fenomena dengan mengkaji data sekunder.

Berkenaan dengan pendekatan yuridis normatif yang digunakan, maka penelitian yang dilakukan melalui studi kepustakaan. Penelitian kepustakaan (library research) adalah suatu penelitian yang dilakukan untuk mempelajari, mengkaji dan menganalisis data sekunder yang berupa bahan hukum primer, sekunder dan tersier. Bahan hukum primer sebagai bahan hukum yang diperoleh langsung dari berbagai peraturan perundang-undangan mulai dari UUD 1945 hingga ketentuan hukum yang bersifat teknis yang berkaitan erat dengan perlindungan konsumen.

Studi kepustakaan juga meliputi bahan-bahan hukum sekunder berupa literatur, karya ilmiah, makalah, hasil penelitian, loka karya, bahan kuliah yang 
berkaitan dengan materi yang diteliti. Untuk melengkapi dan menjelaskan materi bahan-bahan hukum primer dan sekunder, digunakan bahan tersier. Penelitian lapangan (field research) ini dimaksudkan untuk mendapat data primer, tetapi diperlukan hanya untuk menunjang dan melengkapi data sekunder dalam data kepustakaan. Bahan hukum primer sebagai bahan hukum yang diperoleh langsung dari berbagai peraturan perundang-undangan yang terkait dengan perpajakan.

\section{PEMBAHASAN}

\section{A. Pengaturan Mengenai Tarif Bea Masuk E-Commerce}

Banyak orang lebih senang menyebut dengan singkat bea cukai. Sebenarnya yang dimaksud adalah Direktorat Jenderal Bea dan Cukai (DJBC), atau dapat pula yang dimaksud adalah pegawai DJBC. di forum internasional bagi institusi bea cukai digunakan sebutan Administrasi Pabean (Customs Administration) yang ruang lingkup tugasnya meliputi kepabeanan dan cukai atau hanya bidang kepabeanan saja. Kalau melihat masa berlaku ketiga peraturan perundang-undangan produk Belanda yang begitu lama timbul pertanyaan, begitu hebatkah peraturan perundang-undangan itu dalam implementasinya dalam arti memenuhi empat aspek yaitu dapat mencegah penyelundupan, mengoptimalkan penerimaan negara (Bea Masuk dan Pajak Dalam Rangka Impor), memberikan deterent efek yang jitu kepada pelanggar serta dapat mengakomodir semua perkembangan yang terjadi di bidang perdagangan internasional dan kepentingan ekonomi nasional. Pengaturan tarif bea masuk ini dimulai dengan kegiatan impor. Barang-barang impor ini akan diangkut oleh sarana pengangkut dari luar/dalam daerah pabean menuju daerah pabean. Pengangkut yang sarana pengangkutnya akan datang wajib memberitahukan rencana kedatangan sarana pengangkutnya ke kantor pabean tujuan sebelum kedatangan sarana pengangkut. Sarana pengangkut ini dilengkapi dengan dokumen surat muatan, bill of lading untuk sarana pengangkut melalui laut dan airway bill untuk sarana pengangkut udara pengurusan pemberitahuan pabean atas barang impor dilakukan oleh pengangkut/ importir. Dalam hal pengurusan pabean tidak dilakukan sendiri, importir dapat memberikan kuasanya kepada Pengusaha Pengurusan Jasa Kepabeanan (PPJK). Selain diatur dalam UU 
Kepabeanan, PPJK juga diatur dalam Peraturan Menteri Keuangan Nomor 65/PMK.04/2007 tanggal 20 Juni 2007 tentang Pengusaha Pengurusan Jasa Kepabeanan dan Peraturan Direktur Jenderal Bea dan Cukai Nomor P22/BC/2007 tanggal 4 Juli 2007 tentang Petunjuk Pelaksanaan Pemberian Nomor Pokok dan Pengawasan Pengusaha pengurusan Jasa Kepabeanan. Terhadap barang impor dilakukan pemeriksaan pabean.

Pada dasarnya pemeriksaan pabean dilakukan dalam daerah pabean, namun dengan mempertimbangkan kelancaran arus barang dan/atau pengamanan penerimaan negara, Menteri Keuangan dapat menetapkan pelaksanaan pemeriksaan pabean diluar daerah pabean oleh Pejabat bea dan cukai atau pihak lain yang bertindak untuk dan atas nama Direktorat Jenderal Bea dan Cukai. Pemeriksaan pabean diatur dalam Pasal 3 Undang-Undang Nomor 10 Tahun 1995 tentang Kepabeanan sebagaimana telah diubah dengan Undang-Undang Nomor 17 Tahun 2006. Dalam pemeriksaan pabean juga dikenal beberapa penjaluran antara lain jalur merah, jalur hijau, jalur kuning, jalur MITA Non-Prioritas dan jalur MITA Prioritas. Pemeriksaan pabean tidak hanya pemeriksaan fisik saja, melainkan juga pemeriksaan dokumen. Orang yang akan melakukan kewajiban pabean wajib melakukan registrasi ke Direktorat Jenderal Bea dan Cukai untuk mendapatkan nomor identitas dalam rangka akses kepabeanan. Prinsip yang dianut dalam pembayaran bea masuk adalah asas perhitungan sendiri (self assessment). Namun, Pejabat bea dan cukai tetap diberi kewenangan untuk meneliti dan menetapkan tarif dan nilai pabean untuk perhitungan bea masuk yang tersebut dalam pemberitahuan pabean yang diserahkan importir. Penetapan tarif dan nilai pabean diberikan sebelum atau sesudah pemberitahuan pabean atas impor yang diserahkan. Importir yang salah memberitahukan nilai pabean untuk menghitung bea masuk sehingga mengakibatkan kekurangan pembayaran bea masuk dikenai sanksi administrasi berupa denda paling banyak 500\% (lima ratus persen) dari bea masuk yang kurang dibayar atau paling sedikit 100\% (seratus persen) dari bea masuk yang kurang dibayar. Sanksi berupa denda ini diatur dalam Peraturan Pemerintah Nomor 28 Tahun 2008 tentang Sanksi Administrasi berupa denda di Bidang Kepabeanan. 
Penetapan klasifikasi barang dan nilai pabean oleh Direktur Jenderal Bea dan Cukai dibedakan menjadi 2 yaitu pre-entry classification dan valuation ruling, yang dimaksud dengan pre-entry classification yaitu penetapan klasifikasi barang oleh Direktur Jenderal Bea dan Cukai terhadap importasi barang sebelum diajukan pemberitahuan pabean atas permohonan importir. Yang dimaksud dengan valuation ruling yaitu penetapan nilai pabean oleh Direktur jenderal Bea dan Cukai yang dibuat berdasarkan hasil audit kepabeanan terhadap importasi barang yang telah dan akan dilakukan oleh importir dalam jangka waktu tertentu. Bea masuk, cukai, denda administrasi dan pajak dalam rangka impor dapat dibayarkan oleh wajib bayar (importir) melalui: Bank Devisa Persepsi, Kantor Pabean dan Kantor Pos (PT. Pos Indonesia). Yang harus dipersiapkan oleh wajib bayar adalah formulir Pemberitahuan Impor Barang (PIB) atau PIB tertentu kecuali atas kiriman Pabean melalui Pos, formulir Surat Setoran Bea dan Cukai (SSBC) dan Surat Setoran Pajak (SSP) kecuali jika membayar di kantor pabean dan uang pembayaran sejumlah yang tercantum pada PIB/PIB Tertentu atau Penetapan Pencacahan dan Pembeaan Kiriman Pos (PPKP).

Di dalam pengurusan dokumen PIB, perlu diperhatikan dokumen-dokumen pendukung sebagai salah satu dasar dalam penelitian / pemeriksaan dokumen PIB antara lain: Invoice, Bill of Lading (B/L) atau Airway Bill (AWB), Packing List, Bukti Pembayaran (SSBC/BPBC), surat kuasa untuk penyelesaian oleh PPJK, Angka Pengenal Impor (API)/APIT yang masih berlaku, copy Nomor Pokok Wajib Pajak (NPWP). Fasilitas Kemudahan Impor Tujuan Ekspor (KITE) dalam Keputusan Direktur Jenderal Bea dan Cukai Nomor KEP-205/BC/2003 tentang Petunjuk Pelaksanaan Tata Laksana Kemudahan Impor Tujuan Ekspor dan Pengawasannya terakhir kali diubah dengan Peraturan Direktur Jenderal Bea dan Cukai Nomor PER-9/BC/2011 didefinisikan sebagai pemberian pembebasan dan/atau pengembalian Bea Masuk (BM) dan/atau Cukai serta PPn dan PPnBM tidak dipungut atas impor barang dan/atau bahan untuk diolah, dirakit, atau dipasang pada barang lain yang hasilnya terutama untuk tujuan ekspor. Fasilitas Kemudahan Impor Tujuan Ekspor (KITE) yang berupa pemberian pembebasan dan atau pengembalian bea masuk dan atau cukai serta Pajak Pertambahan Nilai 
dan Pajak Penjualan atas Barang Mewah tidak dipungut diberikan untuk memacu ekspor terutama ekspor non-migas. Dengan fasilitas ini pada pengusaha yang melakukan pengolahan terhadap barang impornya dan ditujukan untuk diekspor maka dapat mengajukan pembebasan atau pengembalian. (Rani Maulida, 2019)

Menurut Adrian Sutedi, fasilitas yang diberikan kepada pengguna jasa kepabeanan adalah tidak dipungut bea masuk, pembebasan bea masuk, pembebasan atau keringanan bea masuk dan pengembalian bea masuk. (Adrian Sutedi, 2012: 75-77) Menurut WCO Handbook for Commercial Fraud Investigators ada 16 (enam belas) tipe pelanggaran utama dibidang kepabeanan, yaitu sebagai berikut: penyelundupan, uraian barang yang tidak benar, pelanggaran nilai barang, pelanggaran negara asal barang, pelanggaran fasilitas keringanan bea masuk atas barang yang diolah, pelanggaran impor sementara, pelanggaran perizinan impor/ekspor, pelanggaran transit barang, pemberitahuan jumlah muatan barang yang tidak benar, pelanggaran tujuan pemakaian, pelanggaran spesifikasi barang dan perlindungan konsumen, barang melanggar hak atas kekayaan intelektual, transaksi gelap, pelanggaran pengembalian bea, usaha fiktif dan likuidasi palsu.(World Costums Organization, 2013)

Dalam Peraturan Pemerintah Nomor 28 Tahun 2008 tentang Pengenaan Sanksi Administrasi berupa denda di Bidang Kepabeanan dijelaskan pada pasal 2 tentang denda, pasal 4 tentang tingkatan pelanggaran beserta dendanya, pasal 6 tentang besarnya denda yang disebabkan oleh kekurangan pembayaran bea masuk atau bea keluar, pasal 7 tentang besarnya denda yang disebabkan oleh penyalahgunaan fasilitas, pasal 8 tentang sanksi administrasi berupa denda terhadap pelanggaran atas tarif akhir bea masuk yang besarnya $0 \%$, pasal 9 tentang pelanggaran yang ditemukan berdasarkan hasil audit.

\section{B. Pengaruh Dari Penetapan Penurunan Tarif Pembebasan Bea Masuk Terhadap Kesejahteraan Rakyat Indonesia}

Pada dasarnya barang di luar daerah pabean sejak memasuki (melintas daerah pabean) sudah terutang bea masuk, tetapi dalam hal barang yang dimasukkan tersebut tidak diimpor untuk dipakai, barang tersebut tidak dipungut bea masuk tanpa syarat apapun. Pembebasan disini diartikan sebagai peniadaan kewajiban 
membayar bea masuk karena alasan tertentu yang diatur pada ketentuan kepabeanan. Pada praktiknya pembebasan yang diberikan dilakukan setelah semua syarat dan prosedut yang ditetapkan telah terpenuhi. Pembebasan bea masuk ini bertujuan untuk meperlancar arus barang dalam sistem atau tata laksana kepabeanan di bidang impor. Namun disisi lain banyak pengaruh buruk yang timbul karena adanya pembebasan bea masuk yang terbilang masih cukup tinggi. Dari segi tujuan dari pembebasan bea masuk yaitu memperlancar arus dalam kegiatan impor, artinya memberikan kemudahan atas masuknya produk-produk dari luar negeri ke Indonesia. Kebijakan impor sebagai suatu kebijakan jangka pendek tentunya memiliki dampak terhadap bangsa Indonesia secara ekonomi maupun sosial. Dampak yang diterima bangsa Indonesia adalah pengeluaran devisa negara yang cukup besar untuk melaksanakan impor. Dengan adanya pembebasan bea masuk artinya menambah pengeluaran visa yang harus dikeluarkan oleh negara. Kedua, kegiatan impor juga menciptakan pengangguran, pembebasan bea masuk mepermudah kegiatan impor artinya pemebebasan bea masuk juga merupakan sarana untuk menciptakan lebih banyak pengangguran. Dengan Indonesia selalu mengimpor barang dari luar negeri, maka Indonesia tidak mempunyai kesempatan untuk memproduksi barang-barang tersebut. Dengan demikian Indonesia telah kehilangan kesempatan untuk membuka lapangan pekerjaan yang tercipta dari proses produksi barang tersebut.

Dari beberapa pengaruh buruk dari pembebasan bea masuk yang masih terbilang cukup besar, dapat kita lihat bahwa pembebasan bea masuk sangat berpengaruh terhadap tingkat kesejahteraan masyarakat. mulai dari biaya yang harus dikeluarkan negara untuk menanggung pembiayaan visa, dimana dana itu bisa kita alihkan untuk kebutuhan masyarakat lainnya. Sampai pada permasalahan yang terjadi langsung pada lingkup masyarakat, berkurangnya lapangan kerja bagi masyarakat.(Meryana, 15 September 2019)

Dalam Peraturan Menteri Nomor 112/PMK.04/2018 pasal 13 ayat (1) dijelaskan mengenai pembebasan bea masuk sebesar maksimal USD 75.00, Penulis disini memberikan solusi untuk diturunkan/dikuranginya biaya pembebasan bea masuk dari maksimal FOB USD 75.00 menjadi maksimal FOB USD 50.00, 
dimana pengurangan ini nantinya dapat mengurangi semua dampak buruk yang telah dipaparkan sebelumnya. Dana dari Pengurangan dari USD 75.00 menjadi USD 50.00 ini dapat dialihkan untuk kebutuhan masyarakat lainya guna meningkatkan kesejahteraan masyarakat. Dengan diberikannya sedikit kesulitan untuk barang impor, berdampak pada kuantitas barang yang masuk kedalam negeri (lebih sedikit dari sebelumnya). Maknanya lebih banyak produk dalam negeri yang nantinya dikonsumsi oleh masyarakat Indonesia sendiri, dengan kata lain peluangpeluang kerja mulai kembali terbuka lebar. Ketika banyak peluang kerja yang terbuka maka pengangguran akan berkurang, dan ini akan sangat berdampak pada kesejahteraan masyarakatnya.

\section{Akibat Dari Penurunan Tarif Bea Masuk Atas Barang Impor}

Penurunan tarif bea masuk oleh Menteri Keuangan Republik Indonesia melalui Peraturan Menteri Keuangan Republik Indonesia No.112/PMK.04/2018 tentang Ketentuan Impor Barang Kiriman yang berlandaskan Undang-Undang No.17 tahun 2006 yang berisi bahwa pembebasan bea masuk barang kirim impor diberikan sebesar FOB USD 75.00 (tujuh puluh lima United State Dollar).

Pembebasan bea masuk yang diturunkan sebelumnya dari USD 100.00 ke USD 75.00 dilakukan untuk melindungi industri kecil dan menengah di dalam negeri dari serbuan barang impor. Dengan kebijakan penurunan pembebasan bea masuk ini menjadi kesetaraan bagi produk lokal yang membayar pajak.

Dampak yang diberikan atas kebijakan penurunan bea masuk kepada kiriman barang yang diatas USD 75.00 dipungut sesuai seluruh nilai pabean barang kiriman, berdampak kepada pengendalian impor dan defisit neraca perdagangan serta menstabilkan nilai tukar Rupiah (Rp) terhadap United States Dollar (USD). Pada bisnis e-commerce yang diperdagangkan secara daring barang impor berdampak kepada penstabilan neraca perdagangan dan kisaran penurunan pembebasan bea masuk USD 75.00 bisa menjadi diturunkan kembali ke USD 50.00 untuk memberikan kesetaraan bagi barang lokal dari barang impor serta penurunan ini untuk menghindari "de minimis value" penyalahgunaan fasilitas bea masuk yang bertujuan komersial. 


\section{KESIMPULAN}

Penurunan tarif bea masuk oleh Menteri Keuangan Republik Indonesia melalui Peraturan Menteri Keuangan Republik Indonesia No.112/PMK.04/2018 tentang Ketentuan Impor Barang Kiriman yang berlandaskan Undang-Undang No.17 tahun 2006 yang berisi bahwa pembebasan bea masuk barang kirim impor diberikan sebesar FOB USD 75.00 (tujuh puluh lima United State Dollar). Pembebasan bea masuk sangat berpengaruh terhadap tingkat kesejahteraan masyarakat. Mulai dari biaya yang harus dikeluarkan negara untuk menanggung pembiayaan visa, dimana dana itu bisa kita alihkan untuk kebutuhan masyarakat lainnya. Sampai pada permasalahan yang terjadi langsung pada lingkup masyarakat, berkurangnya lapangan kerja bagi masyarakat. Solusi untuk diturunkan/dikuranginya biaya pemebebasan bea masuk dari maksimal FOB USD 75.00 menjadi maksimal FOB USD 50.00, dimana pengurangan ini nantinya dapat mengurangi semua dampak buruk yang telah dipaparkan sebelumnya. Dana dari Pengurangan dari USD 75.00 menjadi USD 50.00 ini dapat dialihkan untuk kebutuhan masyarakat lainya guna meningkatkan kesejahteraan masyarakat. Pembebasan bea masuk dilakukan untuk melindungi industri kecil dan menengah di dalam negeri dari serbuan barang impor. Dampak yang diberikan atas kebijakan penurunan bea masuk kepada kiriman barang yang diatas USD 75.00 dipungut sesuai seluruh nilai pabean Barang Kiriman, berdampak kepada pengendalian impor dan defisit neraca perdagangan serta menstabilkan nilai tukar Rupiah (Rp) terhadap United States Dollar (USD). 


\section{DAFTAR PUSTAKA}

Bank Indonesia. (2019, 18 September). Data Statistik Sistem Pembayaran diakses dari www.bi.go.id/id/statistik/sistem-pembayaran/uang elektronik/contents/transaksi.aspx (diakses pada 18 September 2019, 17.00 WIB)

Kementerian Keuangan. (2019, 18 September). Penjelasan atas Undang Undang Republik Indonesia Nomor 10 Tahun 1995 tentang Kepabeanan Umum diakses dari https://jdih.kemenkeu.go.id/fullText/1995/10tahun 1995UULamp1.html (diakses pada 18 September 2019, 13.27 WIB)

Krismonika. (2017, 16 September). Dampak Barang Import Dalam Mencapai Ketahanan Pangan di Indonesia, diakses dari https://medium.com/@kimonkrismon/dampak-barang-import-dalammencapai-ketahanan-pangan-di-indonesia-952deb65f9c6 (diakses pada 16 September 2019, 18.48 WIB)

Maulida, R. (2018, 15 September). Bea Masuk : informasi terbaru dan penjelasan yang perlu Anda ketahui, diakses dari https://www.online-pajak.com/beamasuk (diakses pada 15 September 2019, 13.00 WIB)

Meryana, E. (2012, 15 September). Mendag: Kecil, Dampak Pembebasan Bea Masuk Kedelai, Diakses dari https://money.kompas.com/read/2012/07/25/18534684/mendag.kecil.dam pak.pembebasan.bea.masuk.kedelai (diakses pada tanggal 15 September 2019, 15.43 WIB)

Undang Undang Dasar Negara Republik Indonesia Tahun 1945

Undang Undang Nomor 19 Tahun 2019 tentang Informasi dan Transaksi Online. 